\title{
E-Banking and Consumer Debt
}

\author{
Stanko Dimitrov ${ }^{1}$ \\ Phone: (519) 888-4567 ext. 38966 \\ Email: sdimitrov@uwaterloo.ca \\ Brian Paul Cozzarin ${ }^{1}$ \\ Phone: (519) 888-4567 ext. 33291 \\ Email: bpcozzar@uwaterloo.ca
}

\begin{abstract}
Canadian consumers have a debt problem, and averaged a nationwide debt-to-income ratio of 1.654 in 2016. Based on current research, it is unclear whether e-banking has a positive or negative impact on this ratio. This paper hypothesises that e-banking increases consumer access to capital, and - using Canadian nationwide survey data - discovers that e-banking enhances the consumer's ability to access debt, thus leading to an increase of the debt-to-income ratio by two dollars more for every dollar earned. We suspect that the higher willingness to pay, along with preferring to be rejected for a loan via a web portal, leads to customers using ebanking to request loans via an e-banking portal as opposed to going to the bank. Concluding, this paper recommends an increase in government monitoring of the relationship between ebanking and personal debt.
\end{abstract}

Keywords: consumer debt; electronic banking; debt-to-income ratio; Canadian Financial Capability Survey

\section{Introduction}

\footnotetext{
${ }^{1}$ Department of Management Sciences, University of Waterloo, Waterloo ON N2L 3G1, Canada
} 
More than two thirds of Canadians bank online according to Wood (2016). This is good news for banking institutions, as Xue, Hitt and Chen (2011) noticed a lower transaction cost of \$0.01 per transaction via online banking (i.e., e-banking), in comparison to ATMs and bank branches at \$0.27 and \$1.07, respectively. Hitt and Frei (2002) stated that these cost savings translate to a higher profitability for e-banking customers versus traditional customers. However, Martins, Oliveira and Popovič (2014) show that e-banking is also good news for customers, as they can avoid a trip to the branch or to an ATM, thereby saving time and transportation costs.

Multiple authors in the current literature consider a bank's perspective to address which factors (customer-based or product-based) lead to e-banking adoption (Gerrard and Barton Cunningham, 2003; Kolodinsky, Hogarth and Hilgert, 2004; Pikkarainen et al., 2004; Martins, Oliveira and Popovič, 2014; Safeena, Kammani and Date, 2014; Singh and Malhotra, 2015; Yaseen and El Qirem, 2018; Anouze and Alamro, 2019; Chikondi Daka and Phiri, 2019; Gayan Nayanajith, Weerasiri and Damunupola, 2019). Therefore, current literature only examines how banks benefit from e-banking (Hitt and Frei, 2002; Xue, Hitt and Chen, 2011; Yang et al., 2018). While there is some research that examines personal factors which lead to personal debt as well as debt delinquency (Lea, Webley and Levine, 1993; Lea, Webley and Walker, 1995; Li et al., 2020), there is no literature available that investigates whether e-banking has an adverse financial effect on consumers.

Canadian consumers have a debt problem, as the nationwide debt-to-income ratio is 1.654 (Canadian-Press, 2016). Based on current literature, it is unclear whether e-banking has a positive or negative impact on this ratio. While e-banking allows consumers to monitor their debt situation and thereby reducing their debt-to-income ratio, e-banking can also entice consumers to use more banking and debt services, resulting in a higher debt-to-income ratio. Using an instrumental 
variable approach, this paper shows that e-banking has a causal effect on consumers' debt-to-come ratio, as e-banking households carry a debt-to-income ratio 1.42 times greater on average than traditional customers. Raddon-Financial-Group found in a study (Raddon-Financial-Group, 2014) that, while e-banking is growing in popularity it should be used carefully by consumers, as it may lead to increased consumer debt. Garber et al. (2019) suggested that increased household debt in Canada may be a precursor to a national recession, suggesting government may want to help control household debt.

\section{$2 \quad$ Related work and hypothesis}

Consumer debt is a relevant topic in academic, governance, and business domains. Most research uses either proprietary data from one financial institution’s database (Hitt and Frei, 2002; Xue, Hitt and Chen, 2011; Yang et al., 2018), or surveys administered via national institutions or by researchers themselves (Chien and Devaney, 2001; Loke, Yen and Tan, 2013; Basnet and DonouAdonsou, 2016). Each of these approaches provides different perspectives on the issue. For example, Hitt and colleagues (Hitt and Frei, 2002; Xue, Hitt and Chen, 2011) show that e-banking is more profitable than traditional banking from a financial institution perspective.

This paper takes a consumer perspective, and uses similar surveys administered by national institutions in prior research. Such surveys address the following issues: the role of internet access regarding credit card debt in the US (Basnet and Donou-Adonsou, 2016), the role of attitude towards credit regarding credit card balances (Chien and Devaney, 2001), and how families save (Fisher and Montalto, 2011). In addition, multiple studies investigate e-banking diffusion (Gerrard and Barton Cunningham, 2003; Pikkarainen et al., 2004; Laforet and Li, 2005). The common 
thread amongst all these studies is the perceived risk of e-banking as the main differentiating factor by country. Other common findings for diffusion were ease and convenience of use of e-banking.

Already, multiple studies exist that consider psychological and socioeconomic factors that lead to increased personal debt (Lea, Webley and Levine, 1993; Lea, Webley and Walker, 1995; Norvilitis et al., 2006). These studies find that personal income, consumer perception of debt, and how money is spent are all factors that lead to an increase in personal debt. In this study, no data is used for the psychological factors of respondents, but socioeconomic and various demographic factors that lead to increased debt are controlled for, as identified in other literature. In this study's dataset, differential household debt is observed as shown in figure 1.

[insert Figure 1 about here]

The dots shown in figure 1 are not data points per se, but instead are centroids of at least 15 household observations, as is required by Statistics Canada's privacy restrictions. The left panel (fig. 1) suggests that for households that bank online, the debt-to-income ratio is constant, i.e., as household income increases, household debt increases. The right panel suggests that for households that do not bank online, the relationship is much weaker, if non-existent. While this does not allow for a definition of causality, it does define an age and family profile of those who use e-banking. In the 1960's, Modigliani and Ando (1963) defined an economic theory that households use debt to keep consumption roughly equal throughout the lifecycle. This theory has not withstood the test of time as e-banking was introduced, as data shows that households do not "smooth out" their incomes over time. Instead, the profile is that of a concave function (i.e., an 
inverted checkmark) wherein early household debt is low, climaxes during childbearing years, and declines thereafter (Laibson and Harris, 2001; Laibson, 2002).

E-banking allows consumers to apply online for a new home equity line of credit, a new credit card, or a new consumer loan. Consumers can also request increases on these debt instruments using e-banking. On the surface, this seems to be a rather benign innovation. But Hurst (2011) shows that debt-to-income ratios rose 55\% from 1990 to 2009, and that young families with children (170\% debt-to-income ratio) and sole parent families with children (227\% debt-to-income ratio) have much higher ratios than average households (148\%).

Moreover, Xue et al. (2011) use transactional customer data from a US bank regarding the adoption of e-banking, and find that within three months of adoption customers open 0.254 more deposit accounts, obtain 0.105 more loans, and use 0.039 more investment accounts on average. Additionally, two studies investigate internet use and credit card debt: Basnet and Donou-Adonsou (2016) use a survey to show that internet access leads to higher credit card debt by about $4 \%$ to 5\% for younger customers; and Chien and Devaney (2001) show that debt is related to various factors such as marital and professional status, specific credit attitudes, and education. Therefore, it is hypothesised that e-banking enhances credit accumulation, thereby increasing a household's debt-to-income ratio:

$\mathbf{H}_{1}$ : E-banking has a positive causal relationship with household debt-to-income ratio.

\section{Data}

This paper uses the Canadian Financial Capability Survey (CFCS) administered approximately every three years by Statistics Canada, with 2014 being the latest survey data available (Canada, 
2014). The voluntary survey uses a complex design along with random stratified sampling across Canada. There are three survey questions that are of crucial importance to this study: total household income, total debt and liabilities, and how respondents typically check balances of their accounts. This paper uses the "check balances online" question $(\mathrm{y} / \mathrm{n})$ as a proxy for potential credit applications, since CFCS does not include a question about online loans. It also uses the standard demographic questions as controls, as suggested by Chien and Devaney (Chien and Devaney, 2001). The summary statistics of variables utilized are presented in table 1.

[insert Table 1 about here]

\section{$4 \quad$ Methodology}

This paper analyses the relationship between e-banking and consumer debt; and to mitigate the effect of income relative to debt (i.e., higher income households typically have higher debt) the debt-to-income ratio for each household is used instead of absolute debt. We also considered using the ratio of debt to assets, however, we examined the debt-asset variable and found many outliers. We chose not to use debt-asset ratio in this analysis since income and debt are readily known to respondents—-from their pay stub and from their bank account. However, assets are far more subjective and difficult to assess since the respondent must provide an answer 'on the spot' as to the value of their capital goods, such as cars, financial instruments, jewelry and their home.

Given the preceding discussion, we only use debt-to-income ratio in this study. In order to establish a causal relationship between e-banking and debt, we use instrumental variable regression (Wright, 1928). While controlled experiments are the standard for establishing causality, in typical 
regression studies such as this it is only possible to establish correlation between the variables of interest. Instrumental variable regression is a technique used to establish a causal relationship as the instrument is only correlated with the variable of interest and not correlated with the dependent variable. Each potential instrument is checked for it correlation with e-banking. This study also checks when regressing debt-to-income on e-banking and other covariates that the residual from that regression is not correlated with the instrument. If these two preconditions are met, the instrument is further vetted with the following tests at a 0.05 level of significance - underidentification test (i.e., a Kleibergen-Paap rk LM statistic), weak identification test, Hanson J statistic, and a test for endogeneity (i.e., Wu-Hausman F statistic). After these tests, the study retains only the remaining instruments. All regressions are corrected for heteroskedasticity using Huber-White standard errors and are clustered by Canadian province. This study then clusters by province since the error terms are expected to be correlated within a given province but not correlated between provinces. This is assumed because Canadian provinces differ in terms of personal tax rates, and consumer policies. For the continuous dependent variable case (i.e., debtto-income ratio) standard two-stage least squares is used. For the dichotomous dependent variable case (i.e., e-banking) probit instrumental variable regression is used.

\section{$5 \quad$ Results and implications}

Agarwal and Hauswald (2008) point out that banks know the credit risk of every loan applicant, and can easily summarize household and financial characteristics for e-banking loan applicants versus traditional applicants. Traditional applicants have the added advantage of trust relationships with their local branch (Mukherjee and Nath, 2003), while e-banking customers do not: The ebanking application is algorithmic and there is no trust relationship between the online application 
and the customer. The online application is designed to price the loan to account for risk (Agarwal and Hauswald, 2008). This means, a higher risk applicant has a higher probability of obtaining credit online, through trying multiple lenders, than in a face-to-face transaction. For the lowerquality customer, the algorithm simply adjusts the annual percentage rate to account for the higher risk (i.e., a risk premium is added to the APR).

This research tested 297 potential instruments from the survey. From the first part of instrument selection, 38 instruments are identified for the debt-asset (OLS) regression along with 59 instruments for the e-banking (probit) regression. For the debt-to-asset regressions, 16 instruments remained after final testing. For the e-banking probit regressions, only 3 instruments remained. Table 2 summarizes the results for the marginal effect of e-banking on the debt-toincome ratio, while table 3 summarizes the results for the average marginal effect of debt-toincome on e-banking. Table 2 shows that if e-banking= 1 then the debt-to-income ratio increases on average by 1.42. This is a significantly large change. Table 3 contains the effect of changing the debt-to-income ratio by $\mathrm{x} \%$ above the mean value (0.626) increases the probability $\mathrm{y} \%$ that ebanking $=1$. Three cases are presented (tbl. 3) where debt-to-income increases by $10 \%, 50 \%$ and $100 \%$ respectively: In the first case the probability that e-banking $=1$ increases by $1.3 \%$; in the second case the probability that e-banking $=1$ increases by $6.4 \%$; and in the third case, when the debt-to-income ratio increases by $100 \%$ from 0.626 to 1.252 , the probability that e-banking $=1$ increases by $12.4 \%$. When the debt-to-income ratio changes by a large amount (100\%), it only increases the probability by $12.4 \%$. In contrast, the marginal effect of e-banking on the debt-toincome ratio is large.

[insert Table 2 about here] 
[insert Table 3 about here]

Thus, there may be practical and psychological factors that explain why e-banking leads to an increase in total debt. Canada’s Big Five banks (i.e., TD, RBC, BMO, Scotia, CIBC) all provide online banking that allows customers to apply for a loan or home equity line of credit. Additionally, Canada’s four online-only banks (i.e., Alterna Bank-alternabank.ca, EQ Bank-eqbank.ca, Simplii Financial-simplii.com, Tangerine Bank-tangerine.ca) are specifically designed for customers to acquire credit easily and quickly. Prelec and Simester (2001) find that with access to credit, as measured by credit-card use, consumers have a higher willingness to pay. In addition, they preferred modes of communication, customers that are unsure or have low confidence, for example on the likelihood of getting a loan, prefer to use e-mail to communicate rather than a face-to-face meeting. Based on this study, it is assumed that the higher willingness to pay, along with preferring to be rejected for a loan via a web portal, leads to customers using e-banking to request loans via an e-banking portal as opposed to going to the bank. This provides practical insights to financial institutions, as they may see more success in offering hassle-free loans to e-banking customers. Meanwhile, consumers may request to have that option removed if they find themselves using online portals for loans option more than preferred.

\section{Conclusion}

This research shows that there is a statistically significant causal relationship between e-banking and customers' debt-to-income ratio. Though the causality is bi-directional, the effects are far 
greater in terms of e-banking's impact on the debt-to-income ratio. It is unfortunate that no actual transaction-level data is made available by banking institutions. Therefore, the results presented in this study offer only an indirect test of e-banking and the accumulation of debt. Thus, more research with better data is warranted, although this begs the question: Would it be in the bank's interest to release transaction-level data for in-person versus online debt acquisition? Considering the drawbacks of this study, researchers can still advocate for consumers as e-banking is proven to be associated with higher debt-to-income ratios. As it is easier to obtain credit online - even when applicants have lower credit ratings and higher probabilities of default - consumers should be aware of this issue. Based on this research, governments should be encouraged to monitor the situation.

The presented study suggests there may be a link between e-banking and higher personal debt, though the available data is limited to a single year. Individual transaction data would further address any endogeneity issues with current study data. As such, future research could verify this study with individual transaction data. Another avenue of future research could be surveying individuals using e-banking that exhibit higher debt to determine how they use e-banking in their debt accumulation. We currently speculate that easy access to a personal line of credit may result in higher debt, understanding if individuals consciously or unconsciously take on debt will inform future government regulation.

\section{References}

Agarwal, S. and Hauswald, R. (2008) The Choice between Arm 's-Length and Relationship Debt : Evidence from eLoans. Chicago.

Anouze, A. L. M. and Alamro, A. S. (2019) 'Factors affecting intention to use e-banking in Jordan’, International Journal of Bank Marketing, 38(1), pp. 86-112. doi: 10.1108/IJBM-102018-0271.

Basnet, H. C. and Donou-Adonsou, F. (2016) 'Internet, consumer spending, and credit card 
balance: Evidence from US consumers', Review of Financial Economics, 30, pp. 11-22. doi: 10.1016/j.rfe.2016.01.002.

Canada, S. (2014) Canadian Financial Capability Survey. Ottawa: Statistics Canada.

Canadian-Press (2016) ‘Canada’s debt-to-income ratio sets new record high at 165\%', CBC, 11 March. Available at: http://www.cbc.ca/news/business/debt-income-1.3486811.

Chien, Y.-W. and Devaney, S. A. (2001) 'The Effects of Credit Attitude and Socioeconomic Factors on Credit Card and Installment Debt', Journal of Consumer Affairs. Blackwell Publishing Ltd, 35(1), pp. 162-179. doi: 10.1111/j.1745-6606.2001.tb00107.x.

Chikondi Daka, G. and Phiri, J. (2019) 'Factors Driving the Adoption of E-banking Services Based on the UTAUT Model', International Journal of Business and Management, 14(6), p. 43. doi: 10.5539/ijbm.v14n6p43.

Fisher, P. J. and Montalto, C. P. (2011) 'Loss Aversion and Saving Behavior: Evidence from the 2007 U.S. Survey of Consumer Finances', Journal of Family and Economic Issues. Springer US, 32(1), pp. 4-14. doi: 10.1007/s10834-010-9196-1.

Garber, G. et al. (2019) 'Household debt and recession in Brazil', in Handbook of US Consumer Economics. Elsevier, pp. 97-119. doi: 10.1016/B978-0-12-813524-2.00004-4.

Gayan Nayanajith, D. A., Weerasiri, R. A. S. and Damunupola, K. A. (2019) 'A Review on EBanking Adoption in the Context of E-Service Quality', Sri Lanka Journal of Marketing, 5(2), p. 25. doi: 10.4038/sljmuok.v5i2.28.

Gerrard, P. and Barton Cunningham, J. (2003) 'The diffusion of Internet banking among Singapore consumers', International Journal of Bank Marketing. MCB UP Ltd, 21(1), pp. 1628. doi: $10.1108 / 02652320310457776$.

Hitt, L. M. and Frei, F. X. (2002) 'Do Better Customers Utilize Electronic Distribution Channels? The Case of PC Banking', Management Science. INFORMS, 48(6), pp. 732-748. doi: 10.1287/mnsc.48.6.732.188.

Hurst, M. (2011) Debt and family type in Canada, Canadian Social Trends. Ottawa, ON, Canada.

Kolodinsky, J. M., Hogarth, J. M. and Hilgert, M. A. (2004) 'The adoption of electronic banking technologies by US consumers', International Journal of Bank Marketing. Emerald Group Publishing Limited, 22(4), pp. 238-259. doi: 10.1108/02652320410542536.

Laforet, S. and Li, X. (2005) 'Consumers' attitudes towards online and mobile banking in China', International Journal of Bank Marketing. Emerald Group Publishing Limited, 23(5), pp. 362-380. doi: 10.1108/02652320510629250.

Laibson, D. (2002) 'Golden Eggs and Hyperbolic Discounting', The Quarterly Journal of Economics, 112(2), pp. 443-478. doi: 10.1162/003355397555253.

Laibson, D. and Harris, C. (2001) 'Dynamic choices of hyperbolic consumers', Econometrica, 69(4)(4), pp. 935-957.

Lea, S. E. G., Webley, P. and Levine, R. M. (1993) 'The economic psychology of consumer debt', Journal of Economic Psychology, 14(1), pp. 85-119. doi: 10.1016/0167-4870(93)90041-I.

Lea, S. E. G., Webley, P. and Walker, C. M. (1995) 'Psychological factors in consumer debt: 
Money management, economic socialization, and credit use', Journal of Economic Psychology. North-Holland, 16(4), pp. 681-701. doi: 10.1016/0167-4870(95)00013-4.

Li, J. et al. (2020) 'Impact of Medical Debt on the Financial Welfare of Middle- and LowIncome Families across China', International Journal of Environmental Research and Public Health, 17(12), p. 4597. doi: 10.3390/ijerph17124597.

Loke, Y. J., Yen, S. T. and Tan, A. K. G. (2013) 'Credit Card Ownership and Debt Status in Malaysia’, The Singapore Economic Review, 58(03), p. 1350016. doi: 10.1142/S0217590813500161.

Martins, C., Oliveira, T. and Popovič, A. (2014) 'Understanding the Internet banking adoption: A unified theory of acceptance and use of technology and perceived risk application', International Journal of Information Management, 34(1), pp. 1-13. doi: 10.1016/j.ijinfomgt.2013.06.002.

Modigliani, F. and Ando, A. (1963) 'The " Life Cycle " Hypothesis of Saving : Aggregate Implications and Tests', American Economic Review, 53(1), pp. 55-84.

Mukherjee, A. and Nath, P. (2003) 'A model of trust in online relationship banking', International Journal of Bank Marketing, 21(1), pp. 5-15. doi: 10.1108/02652320310457767.

Norvilitis, J. M. et al. (2006) 'Personality Factors, Money Attitudes, Financial Knowledge, and Credit-Card Debt in College Students1', Journal of Applied Social Psychology. Blackwell Publishing Inc, 36(6), pp. 1395-1413. doi: 10.1111/j.0021-9029.2006.00065.x.

Pikkarainen, T. et al. (2004) 'Consumer acceptance of online banking: an extension of the technology acceptance model', Internet Research. Emerald Group Publishing Limited, 14(3), pp. 224-235. doi: 10.1108/10662240410542652.

Raddon-Financial-Group (2014) The Growth of Online Banking Has Caught Up to Lobby/Drive Up Usage | The Raddon Report. Available at: http://www.theraddonreport.com/?p=10941.

Safeena, R., Kammani, A. and Date, H. (2014) 'Assessment of Internet Banking Adoption: An Empirical Analysis', Arabian Journal for Science and Engineering, 39(2), pp. 837-849. doi: 10.1007/s13369-013-0707-x.

Singh, B. and Malhotra, P. (2015) 'Adoption of Internet Banking: An Empirical Investigation of Indian Banking Sector', The Journal of Internet Banking and Commerce. Research and Reviews, 2004.

Wood, E. E. (2016) 68 per cent of Canadians now banking online: Yahoo [infographic] | IT Business. Available at: http://www.itbusiness.ca/news/68-per-cent-of-canadians-now-bankingonline-yahoo-infographic/67372 (Accessed: 17 October 2016).

Wright, P. G. (1928) The tariff on animal and vegetable oils,. New York: The Macmillan Company.

Xue, M., Hitt, L. M. and Chen, P. (2011) 'Determinants and Outcomes of Internet Banking Adoption’, Management Science. INFORMS, 57(2), pp. 291-307. doi: 10.1287/mnsc.1100.1187.

Yang, S. et al. (2018) 'Does Electronic Banking Really Improve Bank Performance? Evidence in China', International Journal of Economics and Finance, 10(2), p. 82. doi:

10.5539/ijef.v10n2p82. 
Yaseen, S. G. and El Qirem, I. A. (2018) 'Intention to use e-banking services in the Jordanian commercial banks', International Journal of Bank Marketing, 36(3), pp. 557-571. doi: 10.1108/IJBM-05-2017-0082. 


\begin{tabular}{|c|c|c|c|c|c|c|c|c|}
\hline Variable & $\mathrm{N}$ & $5 \%$ & $25 \%$ & $50 \%$ & Mean & $75 \%$ & $95 \%$ & $\sigma^{2}$ \\
\hline debt & 6683 & 0 & 0 & 1000 & 54690 & 50000 & 275000 & 153323 \\
\hline ebank & 6683 & 0 & 0 & 1 & 0.56 & 1 & 1 & 0.50 \\
\hline income & 6683 & 20000 & 41000 & 70000 & 87810 & 110000 & 200000 & 88217.5 \\
\hline $\begin{array}{l}\text { household } \\
\text {-size }\end{array}$ & 6683 & 1 & 1 & 2 & 2.33 & 3 & 5 & 1.29 \\
\hline age & 6683 & 24 & 39.5 & 54 & 53.16 & 66 & 81 & 17.50 \\
\hline sex & 6683 & 1 & 1 & 2 & 1.54 & 2 & 2 & 0.50 \\
\hline marital & 6683 & 1 & 1 & 2 & 2.81 & 5 & 6 & 2.05 \\
\hline school & 6683 & 0 & 3 & 5 & 4.79 & 6 & 9 & 2.60 \\
\hline $\begin{array}{l}\text { current- } \\
\text { job }\end{array}$ & 6683 & 0 & 0 & 5 & 7.39 & 13 & 23 & 7.91 \\
\hline $\begin{array}{l}\text { spouse- } \\
\text { current- } \\
\text { job }\end{array}$ & 6683 & 0 & 0 & 0 & 4.27 & 6 & 21 & 7.07 \\
\hline $\begin{array}{l}\text { debt- } \\
\text { income }\end{array}$ & 6683 & 0 & 0 & 0.017 & 0.626 & 0.658 & 2.857 & 1.80 \\
\hline \multicolumn{9}{|l|}{ Definitions } \\
\hline debt & \multirow{2}{*}{\multicolumn{8}{|c|}{$\begin{array}{l}\text { total household debt, in dollars (mortgages, student loans, payday loans, other loans, credit card } \\
\text { debt, lines of credit, other debts) } \\
\text { binary variable indicating whether the respondent primarily checks account balance(s) online } \\
\text { (no=0, yes=1) }\end{array}$}} \\
\hline ebank & & & & & & & & \\
\hline income & \multicolumn{8}{|c|}{ total household income, in dollars for the past 12 months } \\
\hline $\begin{array}{l}\text { household- } \\
\text { size }\end{array}$ & \multicolumn{8}{|c|}{ number of people in the household } \\
\hline age & \multicolumn{8}{|c|}{ age of the respondent, in years } \\
\hline sex & \multicolumn{8}{|c|}{ sex of the respondent (male $=1$, female $=2$ ) } \\
\hline marital & \multicolumn{8}{|c|}{$\begin{array}{l}\text { marital status of the respondent (married=1, living common-law=2, widowed=3, separated=4, } \\
\text { divorced }=5 \text {, single or never married }=6 \text { ) }\end{array}$} \\
\hline school & \multicolumn{8}{|c|}{$\begin{array}{l}\text { highest level of respondent education (high school or less }=1 \text {, some college or university without } \\
\text { degree }=2 \text {, college or trade or vocational or technical school }=3 \text {, university undergraduate degree }=4 \text {, } \\
\text { university graduate degree and/or professional degree }=5 \text {, not stated }=9 \text { ) }\end{array}$} \\
\hline current-job & \multicolumn{8}{|c|}{$\begin{array}{l}\text { current employment status of the respondent (employed }=1 \text {, self-employed }=2 \text {, not working and } \\
\text { looking for work }=3 \text {, not working and not looking for work }=4 \text {, retired }=5 \text {, a student, including work } \\
\text { programs }=6 \text {, doing unpaid household work }=7 \text {, other }- \text { specify }=8 \text {, do not know }=97 \text {, refusal=98) }\end{array}$} \\
\hline $\begin{array}{l}\text { spouse- } \\
\text { current-job }\end{array}$ & \multicolumn{8}{|c|}{$\begin{array}{l}\text { current employment status of the respondent's spouse (employed=1, self-employed=2, not working } \\
\text { and looking for work=3, not working and not looking for work=4, retired=5, a student--including } \\
\text { work programs=6, doing unpaid household work=7, valid skip=96, do not know=97, refusal=98, } \\
\text { not stated=99) }\end{array}$} \\
\hline $\begin{array}{l}\text { debt- } \\
\text { income }\end{array}$ & \multicolumn{8}{|c|}{ household debt-to-income ratio $=$ debt/income } \\
\hline
\end{tabular}




\begin{tabular}{|l|l|c|}
\hline Table 2: Instruments for e-banking & Marginal effect \\
\hline Instrument name & Description & 1.467 \\
\hline AD_08 & $\begin{array}{l}\text { Total value of any of these assets: Cash savings, } \\
\text { investments, registered disability savings plan, tax free } \\
\text { savings plan, private pensions, other financial assets }\end{array}$ & \\
\hline FC_02A & Source of advice - Accountant & 0.970 \\
\hline FC_02B & Source of advice - Lawyer, notary & 0.958 \\
\hline FC_02G & Source of advice - Insurance company & 0.964 \\
\hline FC_02K & Source of advice - Internet & 0.955 \\
\hline FC_03 & Pay for any advice & 0.951 \\
\hline FM_03A & Unexpected \$5,000 expenditure - Use savings & 1.210 \\
\hline IN_01D & Income - CPP/QPP, OAS, GIS & 2.410 \\
\hline OE_01 & Who is responsible for regular bills & 2.004 \\
\hline OE_11 & Have a household budget & 1.360 \\
\hline OE_12 & How often stay within budget & 1.239 \\
\hline PMKSTAT & Person most knowledgeable - Status & 2.452 \\
\hline TENURE & Housing tenure & 1.830 \\
\hline PAY_BILL & Who is responsible for paying regular bills & 3.115 \\
\hline & & 1.420 \\
\hline Mean effect & & \\
\hline & \multicolumn{2}{|}{} \\
\hline
\end{tabular}




\begin{tabular}{|l|l|c|c|c|}
\hline \multicolumn{2}{|l|}{ Table 3: Debt-to-income ratio and probability of e-banking } \\
\hline & \multicolumn{4}{|c|}{ Increase mean debt-to-income ratio by: } \\
\hline $\begin{array}{l}\text { Instrument for } \\
\text { debt-to-income } \\
\text { ratio }\end{array}$ & Description & $\begin{array}{c}10 \% \\
\text { (debt_inc=0.689) }\end{array}$ & $\begin{array}{c}50 \% \\
\text { (debt_inc=0.939) }\end{array}$ & $\begin{array}{c}100 \% \\
\text { (debt_inc=1.252) }\end{array}$ \\
\hline EF_02 & \begin{tabular}{l}
$|c|$ \\
Pr(ebank = 1) increases by: \\
\hline FC_01I \\
child's post-secondary education
\end{tabular} & 0.014 & .067 & 0.129 \\
\hline FC_05K & $\begin{array}{l}\text { Advice - No, did not use any } \\
\text { advice }\end{array}$ & 0.009 & .047 & 0.092 \\
\hline & $\begin{array}{l}\text { Keep an eye on - None of the } \\
\text { above }\end{array}$ & 0.016 & .079 & 0.152 \\
\hline $\begin{array}{l}\text { Mean } \\
\text { probability }\end{array}$ & & & & 0.124 \\
\hline
\end{tabular}


Appendix A: Instrumental variable regressions for debt-to-income ratio

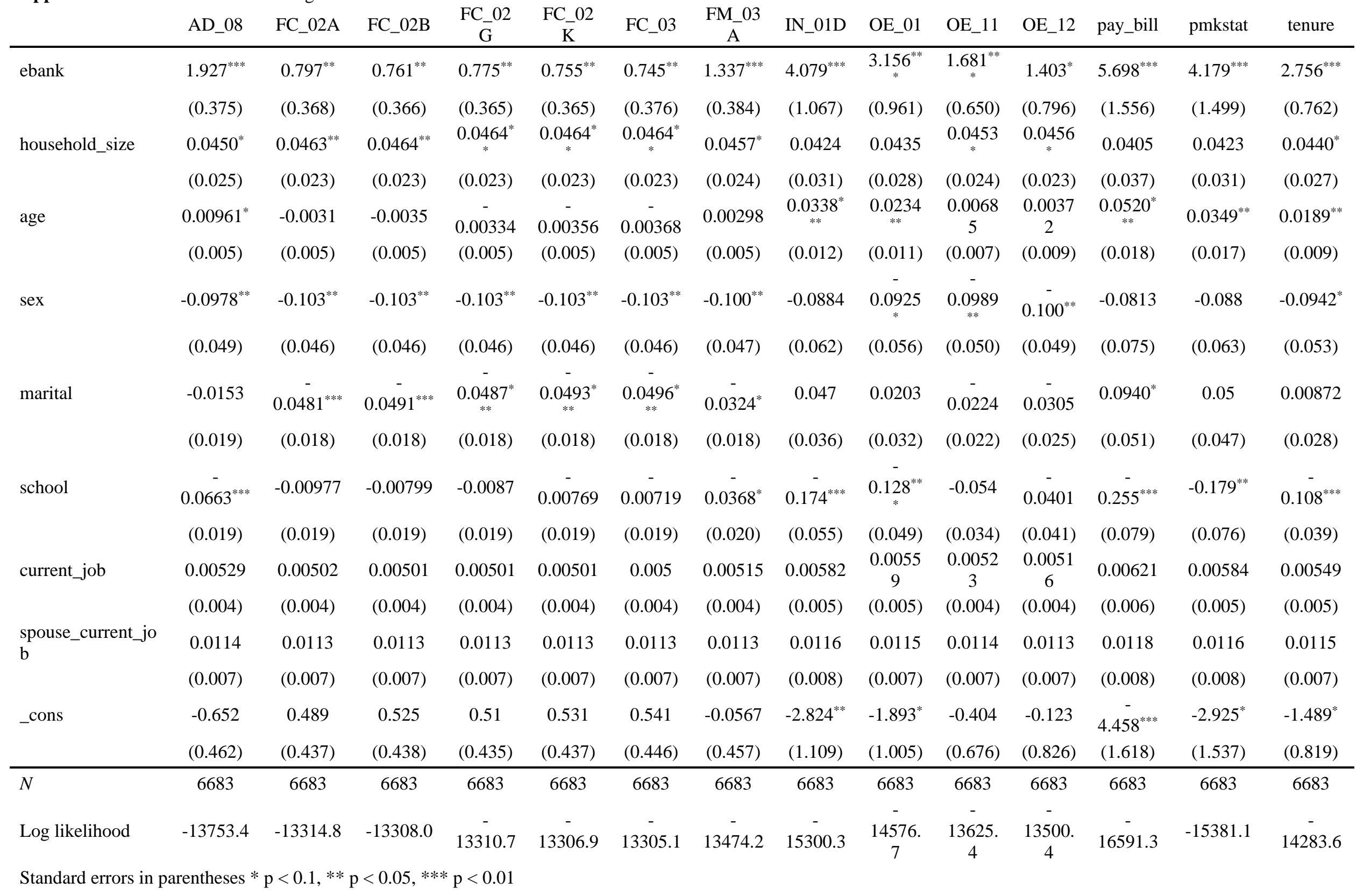


Appendix B: Two-step instrumental variable probit regressions for e-banking

\begin{tabular}{lccc} 
& EF_02 & FC_01I & FC_05K \\
\hline debt_income & $0.558^{* * *}$ & $0.388^{*}$ & $0.663^{*}$ \\
household_size & $(0.132)$ & $(0.204)$ & $(0.387)$ \\
& $-0.0343^{* *}$ & -0.0285 & -0.0416 \\
age & $(0.0143)$ & $(0.0176)$ & $(0.0336)$ \\
& $-0.0290^{* * *}$ & $-0.0312^{* * *}$ & $-0.0279^{* * *}$ \\
sex & $(0.00235)$ & $(0.00296)$ & $(0.00564)$ \\
& 0.0399 & 0.0212 & 0.05 \\
marital & $(0.0411)$ & $(0.042)$ & $(0.0457)$ \\
& $-0.0618^{* * *}$ & $-0.0731^{* * *}$ & -0.0537 \\
school & $(0.0185)$ & $(0.0199)$ & $(0.0387)$ \\
& $0.144^{* * *}$ & $0.149^{* * *}$ & $0.140^{* * *}$ \\
current_job & $(0.0113)$ & $(0.01)$ & $(0.016)$ \\
& $-0.00416^{*}$ & -0.00328 & -0.00459 \\
spouse_current_job & $(0.0024)$ & $(0.00242)$ & $(0.00327)$ \\
& -0.00712 & -0.00523 & -0.00828 \\
_cons & $(0.00454)$ & $(0.00501)$ & $(0.00585)$ \\
& $0.954^{* * *}$ & $1.181^{* * *}$ & 0.829 \\
& $(0.208)$ & $(0.277)$ & $(0.542)$ \\
\hline$N$ & 6683 & 6683 & 6683 \\
Wald chi2 & $2241.87^{* * *}$ & $2866.73^{* * *}$ & $1045.00^{* * *}$ \\
Standard errors in parentheses*p $<0.1, * * \mathrm{p}<0.05, * * * \mathrm{p}<$ \\
& & & \\
& & &
\end{tabular}



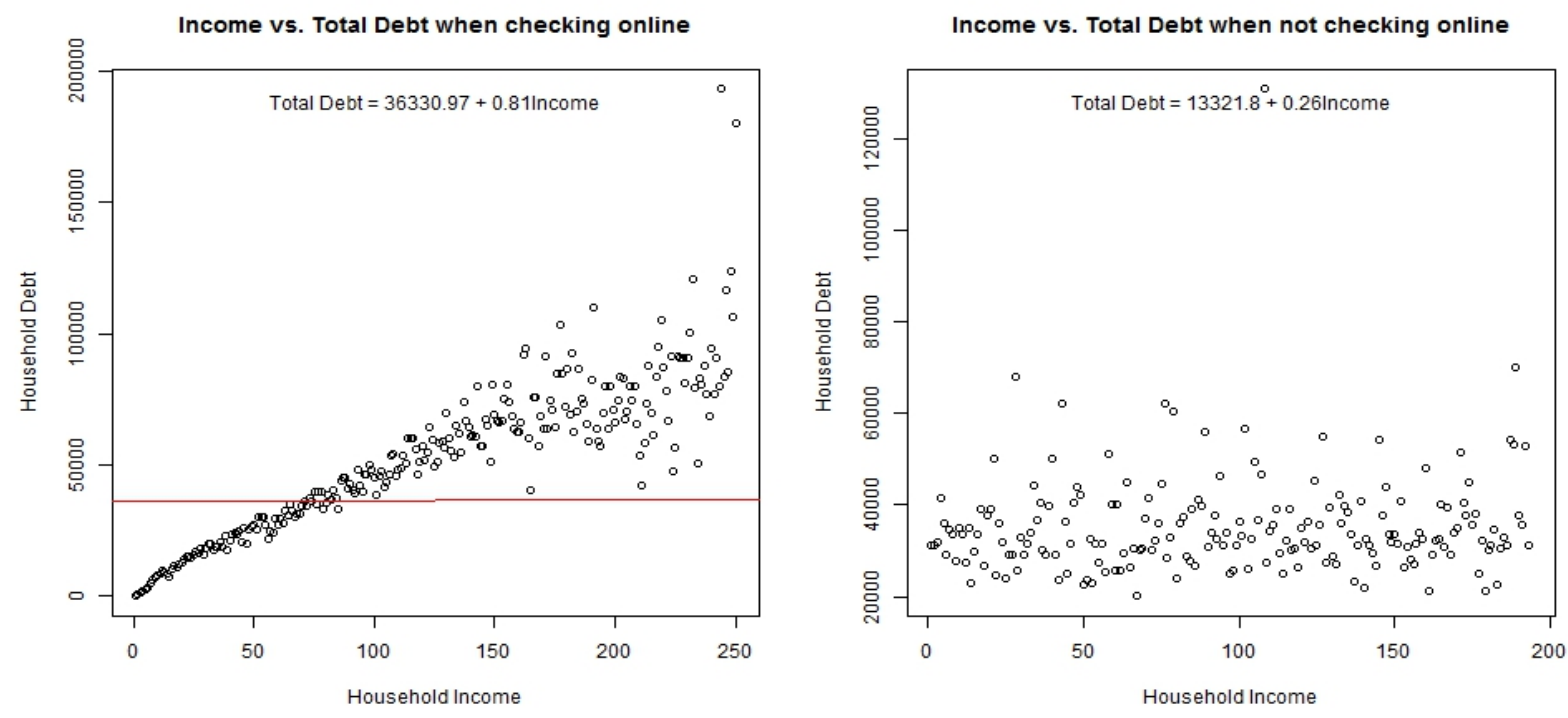

Figure 1: Difference between household debt and income for e-banking and no e-banking groups. Note that each point is the centroid of at least 15 points as per data security requirements. 